\title{
Nutrient Cycling and Retention Along a Littoral Gradient in a Dutch Shallow Lake in Relation to Water Level Regime
}

\author{
S. Sollie • J. T. A. Verhoeven
}

Received: 13 July 2007 / Accepted: 5 March 2008 / Published online: 30 March 2008

(C) The Author(s) 2008

\begin{abstract}
Littoral zones are characterized by gradients in depth and vegetation biomass, influencing nutrient retention capacity. A field experiment was conducted in a Phragmites australis dominated littoral zone to investigate nutrient retention and its effect on surface water quality. Measurements were done in mesocosms where water levels could be manipulated. Nutrient status was investigated along a gradient perpendicular to the shore during two growing seasons, one with a stable water level and one with a gradually decreasing water level. Nutrient concentrations in sediment, soil pore water and surface water were significantly lower in the vegetated than in the unvegetated zone. The negative correlations of nutrients in sediment and water, with nutrient contents of the vegetation suggest a direct effect of the vegetation. Nutrient uptake and biomass of the vegetation was higher in continuously flooded soils than in seasonally emerging sediments higher along the littoral gradient, probably due to the increased salinity in drained zones. Denitrification rate was highest in the unvegetated zone and was
\end{abstract}

S. Sollie · J. T. A. Verhoeven

Section Landscape Ecology, Utrecht University,

Utrecht, The Netherlands

J. T. A. Verhoeven $(\bowtie)$

P.O. Box 80084, 3508 TB Utrecht, The Netherlands

e-mail: j.t.a.verhoeven@uu.nl positively related to water level. Flooded littoral zones did result in a higher nutrient retention than drained zones. On small scale, for an optimal nutrient retention a fluctuating regime is not necessarily better suited than a stable water level, but on a larger scale it can substantially increase the width of the vegetated zone. It is important to optimize conditions for helophyte growth since the positive effect of vegetation on nutrient retention, at least at local scale, has been demonstrated in this study.

Keywords Denitrification - Littoral zone · Nutrient retention Phragmites australis. Shallow lake Water quality

\section{Introduction}

Shallow lakes with low nutrient concentrations usually are dominated by aquatic macrophytes. The aquatic vegetation provides an important refuge for many animals. Zooplankton is protected against fish predation and contributes significantly to the control of phytoplankton biomass (Scheffer 1998). When nutrient loading increases, biomass of the macrophytes will increase initially, but further eutrophication often leads to excessive phytoplankton blooms (Dobson and Frid 1998). This results in increased turbidity, loss of submerged macrophytes due to light limitation, low dissolved oxygen, excessive produc- 
tion of organic matter and toxic gases (hydrogen sulphide, ammonia) and growth of toxic blue-green algae (Scheffer 1998). These impacts are hampering the use of the affected lakes as a source of food, clean water or for recreation. Shallow lakes and adjacent marshy land are also notoriously rich in wildlife. It is therefore of major importance to lower nutrient concentrations and restore turbid lakes to a clear water state.

Measures to lower nutrient concentrations in the surface water should primarily be directed to the reduction of inflow of excess nutrients from point and non-point sources (Köhler et al. 2005). Reduction of excess inflows can, however, often be achieved only partially within acceptable cost limits. Another method to improve water quality in shallow lakes is the restoration or expansion of helophyte zones that are known to be capable of retaining nutrients from the surface water. Many studies (e.g. Coveney et al. 2002; Meuleman et al. 2002; Verhoeven and Meuleman 1999) have shown that helophytes can retain nutrients effectively during the growing season. Helophytes take up nutrients from the sediment or directly from the surface water using adventitious roots (Coops et al. 1996). Evapotranspiration causes a depletion of water near the roots, resulting in a net flow of surface water (including nutrients) into the sediment (Koerselman and Beltman 1988). Most of the studies mentioned have, however, been done in constructed wetlands. The design and management of such wetlands are optimized for nutrient retention in terms of water flow, vegetation biomass, species composition and in some cases mowing regime.

Helophyte stands naturally present as littoral zones along the shores of shallow lakes are also often mentioned as diminishing nutrient concentrations in the lake water (Bratli et al. 1999), but studies of their functioning have been relatively scarce. The degree of nutrient retention and reduction of nutrient concentrations in the surface water is influenced by the relative lake area covered by emergent vegetation and thus by the morphometry of the lake shore, which is often characterized by a depth gradient perpendicular to the shoreline. Dobson and Frid (1998) describe the littoral zone according to different hydrological characteristics. Surface water has the least influence on the part of the littoral zone closest to the land. Only occasionally this zone is flooded with lake water. In the zone within the amplitude of the seasonal water fluctuations, the sediment is alternately flooded and drained depending on seasonal water level and wind and wave action. At the lower end of the gradient, the sediment is flooded year-round. Going from high to low on the lakeshore, vegetation is dominated by emergent helophytes and submerged aquatic plants, respectively, until vegetation is not able to grow due to light limitation.

Littoral vegetation biomass is dependent on water level and its dynamics (Coops et al. 1996). In most of the Dutch shallow lakes water level is kept constant with a non-natural water regime of higher levels in summer than in winter for economic and safety reasons. This limits the presence of littoral vegetation to relatively narrow zones. A more natural water level regime would imply a gradual decrease in water level during summer due to an increasing evapotranspiration and decreased rainfall. Such a water regime would not only create opportunities for much wider zones with littoral vegetation, it would also create different conditions in the sediment with consequences for nutrient retention. Denitrification, for example, is strongly influenced by water level, organic matter content and presence of vegetation (Saunders and Kalff 2001). A full evaluation of the consequences of the restoration of a natural water level regime with wide littoral zones requires quantitative knowledge on the effects of water level fluctuations on nutrient cycling and retention in such zones.

Because little is known about the role of littoral wetlands in shallow lakes (and their different zones) in nutrient removal, a field experiment involving water level fluctuations was conducted in a field scale littoral zone section in Lake Volkerak-Zoom where the water levels could be manipulated. In this experiment the effects of vegetation, water level fluctuations and biogeochemical processes on water quality were investigated, using the following research questions:

1. How do the nutrient retention processes plant uptake, denitrification and sediment sorption differ along the gradient from the land boundary to the open water?

2. Will a natural seasonal water level regime result in a larger nutrient retention/removal in the littoral zone and in lower nutrient concentrations in the surface water compared to a stable water level regime? 


\section{Methods}

\subsection{Site Description}

Lake Volkerak $\left(51^{\circ} 38^{\prime} \mathrm{N} 4^{\circ} 17^{\prime} \mathrm{E}\right)$ is a freshwater lake in the south-western part of the Netherlands. In 1987 the lake was closed off from the North Sea, turning it from a brackish estuary into a freshwater lake. The Lake Volkerak area is 6,450 ha with $25 \%$ marshes and mudflats. The average water depth is $5.2 \mathrm{~m}$ with a maximum of $24 \mathrm{~m}$. The water surface is kept at a constant level and is regulated by several sluices. Since 1994 a serious cyanobacteria problem has existed, because of the excess of nutrients entering the lake via the rivers Mark, Dintel, Meuse and Rhine through the Hollands Diep.

The banks of Lake Volkerak have become much steeper after the closure, because mudflats and shallow shore zones have been eroded as a result of the regulated, constant water level. Together with grazing (both birds and cattle) this has largely prevented the growth of helophytes along the shores of the lake. In a large-scale experiment, part of Lake Volkerak shore (4 ha) was isolated from the lake by dam-walls in 1995 to be able to manage water levels independently of the rest of the lake. Water from the lake can be pumped into or out of the basin, according to the preferred water level regime. From 1995 until 1999, this separated basin has been subjected to a water regime with low water level in spring and summer and high water level in winter (Tosserams et al. 1999). At the same time, grazing was prevented. In the course of 5 years, a rapid increase of helophyte vegetation took place over a width of maximally $65 \mathrm{~m}$ of the shore zone. The vegetation in this zone now mainly consists of Phragmites australis, but also Typha angustifolia, Typha latifolia and Scirpus maritimus were present.

\subsection{Setup}

Inside the 4 ha isolated basin an experiment was carried out during the growing seasons (AprilSeptember) of 2004 and 2005. Plastic cylindrical enclosures $\left(0.45 \mathrm{~m}^{2}\right)$ were used to confine local surface water in one location during the whole season. Without cylinders, mixing between the different zones could obscure spatial differences in nutrient concentrations. A plastic bird protection rim with vertical, triangular thorns was placed on top of the cylinders to prevent birds from sitting on them. The cylinders were placed in three different littoral zones perpendicular to the shoreline: 1 . vegetated, high on the lake shore [vegetated, high $(\mathrm{VH})$ ], 2. vegetated, in the center of the helophyte vegetation [vegetated, center (VC)] and 3. unvegetated, at the lower end of the lake shore, nearest to the open water [unvegetated, low (UL)] (Fig. 1). In each zone five replicate cylinders were placed, approximately $10 \mathrm{~m}$ apart, resulting in a total of 15 cylinders. The cylinders were pressed into the sediment to about $10 \mathrm{~cm}$ deep, so that surface water was kept inside. Water levels were regulated inside the basin (including inside the cylinders) by using the pumping facilities.

Water level was kept at a constant level during the whole growing season in 2004. However, in August 2004 heavy rainfall caused a period of higher water levels than planned. In 2005 it was allowed to decrease steadily from March to September, to mimic a natural water level regime. At the beginning of 2005, the cylinders were repositioned to different heights along the gradient to ensure that the cylinders
Fig. 1 Schematic representation of the zones with experimental cylinders in lake Volkerak. VH vegetated, high on the lake shore, $V C$ vegetated, center, $U L$ unvegetated, low on the lake shore

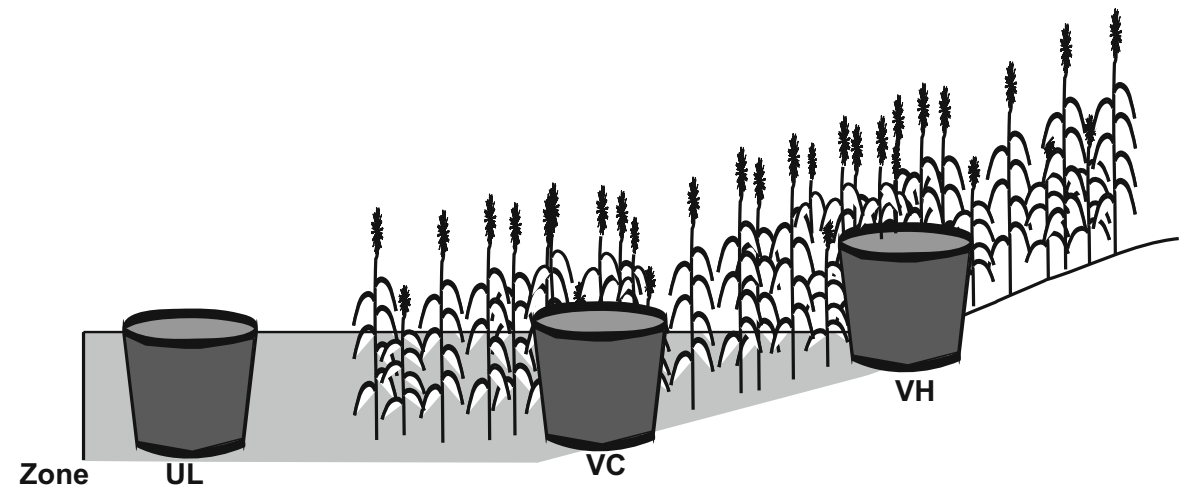


in zone $\mathrm{VH}$ fell dry around mid May and those in zone VC at the end of June. Measurements of surface water, soil pore water and sediment nutrient concentrations were done inside as well as outside the cylinders to determine the cylinder effect. In this experiment only Phragmites australis was studied being the dominant species. Biomass of other species was negligible.

\subsection{Field and Laboratory Techniques}

Water level was measured every half hour, using a pressure sensor ('diver'; Van Essen Instruments). To correct for air pressure, the values measured with a 'baro diver' were subtracted. The water level regime in the experimental basin was continuously adjusted by pumps to meet the preferred regime.

Pore water and surface water (if present) was collected every two weeks. Pore water was sampled in vacuum bottles using rhizons (Rhizon SMS, Eijkelkamp Agrisearch Equipment) permanently placed inside and outside (1 $\mathrm{m}$ distance) the cylinders. Surface water was collected in plastic flasks inside and outside the cylinders. Both were stored in a cooling box, transported to the lab and placed at $4^{\circ} \mathrm{C}$. Within $24 \mathrm{~h}, \mathrm{pH}$ and electrical conductivity (EC) were measured (after filtering surface water) and samples were stored at $-18^{\circ} \mathrm{C}$ until ion measurements at the Skalar Autoanalyser.

Sediment samples $(10 \mathrm{~cm}$ depth $)$ were taken outside the cylinders because of the destructive nature of the sampling procedure. In 2004 samples were taken monthly, in 2005 only during denitrification sampling. The samples were extracted within $24 \mathrm{~h}$ after collection using extraction with demineralized water, $0.2 \mathrm{M} \mathrm{KCl}$ extraction $\left(\mathrm{NH}_{4}^{+}\right.$and $\left.\mathrm{NO}_{3}^{-}\right)($Houba et al. 1989) and Olsen extraction $\left(\mathrm{PO}_{4}^{3-}\right)$ (Bray and Kurtz 1945). For extractions with demineralized water and $\mathrm{KCl}, 100 \mathrm{ml}$ extraction solution was added to $10 \mathrm{~g}$ fresh sediment and shaken for $1 \mathrm{~h}$ followed by 4 minutes of centrifuging at $4,00 \mathrm{rpm}$. In the demineralized water extract $\mathrm{pH}$ and $\mathrm{EC}$ were measured. The samples were then filtered over a $\mathrm{GF} / \mathrm{C}$ Whatman-filter $(1.2 \mu \mathrm{m})$ and stored in the freezer $\left(-8^{\circ} \mathrm{C}\right)$ until further analysis. For Olsen extraction $50 \mathrm{ml}$ of $0.5 \mathrm{M} \mathrm{NaHCO}_{3}$ was added to $5 \mathrm{~g}$ of fresh sediment and shaken for $30 \mathrm{~min}$. After centrifugation and filtration, a mixed reagent was added to the extract after which the samples were measured colorimetrically at $880 \mathrm{~nm}$ for $\mathrm{PO}_{4}^{3-}$. Sediment samples were dried $\left(105^{\circ} \mathrm{C}, 24 \mathrm{~h}\right)$ and digested with a modified Kjeldahl procedure to measure total $\mathrm{N}$ and P (Bremner and Mulvany 1982). Five milliliter of a mixture of sulphuric acid and salicylic acid was added to $750 \mathrm{mg}$ of sediment. A catalyst was added and the solution was heated for $1 \mathrm{~h}$ at $200^{\circ} \mathrm{C}$ followed by $90 \mathrm{~min}$ at $340^{\circ} \mathrm{C}$. When the samples were clear and green, they were cooled and demineralized water was added up to $75 \mathrm{ml}$. After homogenizing the samples, the supernatant was decanted and stored until further analysis on the autoanalyser. Loss on ignition was calculated by igniting $5 \mathrm{~g}$ of dry sediment for $5 \mathrm{~h}$ at $550^{\circ} \mathrm{C}$.

In 2004 plant biomass inside the cylinders was estimated every 2 weeks. Ten reed stems with average stem length were cut at soil surface outside the cylinder and measured for weight (separation of dead and living tissue). The vegetation samples were dried at $70^{\circ} \mathrm{C}$ for $48 \mathrm{~h}$ to measure dry weight. These data, together with the number of stems inside the cylinder were used to calculate living and dead aboveground biomass inside the cylinder. For total $\mathrm{N}$ and $\mathrm{P}, 150 \mathrm{mg}$ of ground biomass was digested with a Kjeldahl procedure. In 2005 aboveground plant biomass was calculated every month. Stem length and stem diameters of twenty randomly chosen stems (every tenth stem) inside the cylinders were measured monthly. Biomass of 50 stems of different length and diameter was determined once at the end of the growing season and used to make a regression of biomass versus shoot length and diameter. This relation was used to calculate aboveground living biomass in the cylinders. At the end of the growing season ten stems with average height were cut inside the cylinder to measure biomass and compare it with the values calculated on the basis of length and diameter. Because these two methods were comparable in the results, it can be assumed that the two methods are comparable and only the biomass values based on calculations using the shoot density and dimension values are shown. TN and TP in the aboveground vegetation were measured as in 2004 .

In April, May and July 2005, denitrification rates were measured just outside the cylinders using the acetylene inhibition method (Ryden et al. 1987). Acetylene was used to inhibit the reduction of $\mathrm{N}_{2} \mathrm{O}$ to $\mathrm{N}_{2}$, so $\mathrm{N}_{2} \mathrm{O}$ was the sole product of denitrification. Fifteen 10-cm-deep cores (diameter $3.5 \mathrm{~cm}$ ) per zone were sampled, wrapped undisturbed in aluminum foil 
(open at the top) and placed per three in a $1.161 \mathrm{jar}$ $(n=5)$. Jars were flushed with $\mathrm{N}_{2}$ to remove accumulated $\mathrm{N}_{2} \mathrm{O}$ and to lower the oxygen content to an anaerobic condition. Jars were closed and $100 \mathrm{ml}$ of acetylene $(10 \% v / v)$ was added with a syringe. After 1 and $5 \mathrm{~h} \mathrm{~N}_{2} \mathrm{O}$ in the headspace was measured on a gas chromatograph (GC Hewlett Packard 5890) equipped with an electron capture detector $\left(\mathrm{ECD}{ }^{63} \mathrm{Ni}\right)$ and Hayesep Q columns. $\mathrm{N}_{2} \mathrm{O}$ dissolved in water was taken into account using the Bunsen coefficient. Denitrification rate was calculated per $\mathrm{m}^{2}$ using the core surface area and the Bunsen coefficient (fraction of $\mathrm{N}_{2} \mathrm{O}$ dissolved in water). Extractable $\mathrm{NH}_{4}^{+}$and $\mathrm{NO}_{3}^{-}$were measured with $0.2 \mathrm{M} \mathrm{KCl}$ extraction in the sediment cores after incubation.

\subsection{Statistics}

All statistical analyses were performed using SPSS 12.0 (SPSS Inc., Chicago Il., USA). To compare between zones or between sampling dates one-way ANOVA was used. When ANOVA indicated significant differences, a post hoc test (Tukey) was performed to identify these differences. Data which did not meet the requirements for ANOVA (Levene test for homogeneity of variance and normal distribution) were analyzed with a nonparametric test (Kruskal-Wallis H). To analyze time series Repeated Measures (RM) was used. When interaction was shown between time and treatment the results of these RM could not be used and ANOVA was used to compare treatments at a certain sampling date. Pearson's Correlation Coefficient was used to test correlations between parameters, while in case of an independent variable regression analysis was used.

\section{Results}

\subsection{Surface Water}

In 2004 zones VC and UL were constantly flooded, whereas zone $\mathrm{VH}$ only contained surface water in August (Fig. 2). In 2005 water level decreased during the season causing emergence of the sediment in zone VH from May on and in zone VC from June on. Zone UL remained always flooded and zone $\mathrm{VH}$ was only flooded in the beginning of the growing season, resulting in only one sampling point. Therefore, only the results of the zones VC and UL are used. Surface water nutrient concentrations were different inside the cylinders compared to outside.

In 2004, surface water ammonium and phosphate showed occasional high peaks in the unvegetated zone, while these concentrations remained continuously low in the vegetated zone (Fig. 3a; significant difference for ammonium between vegetated and unvegetated zones, $p=0.001$ ). These peaks were only found inside the mesocosms and did not occur outside (Fig. 3b). In 2005, only phosphate showed an increasing trend during the growing season inside the unvegetated cylinder, similar to that in 2004, while ammonium did not show any peaks (Fig. 4a). Just like in 2004, the increase was absent outside the mesocosms (Fig. 4b). The nitrate concentrations showed a significant decrease over time in 2005, inside as well as outside the mesocosms.

The surface water in both the vegetated (VC) and the unvegetated (UL) zone had a high EC, ranging from 2 to $5 \mathrm{mS} \mathrm{cm}^{-1}$ and from 1.4 to $2.4 \mathrm{mS} \mathrm{cm}^{-1}$ in 2004 and 2005, respectively (no significant differ-
Fig. 2 Water levels and the relative position of the sediment surface in the different zones, in 2004 (left) and 2005 (right). $V H$ vegetated, high on the lake shore, $V C$ vegetated, center, $U L$ unvegetated, low on the lake shore
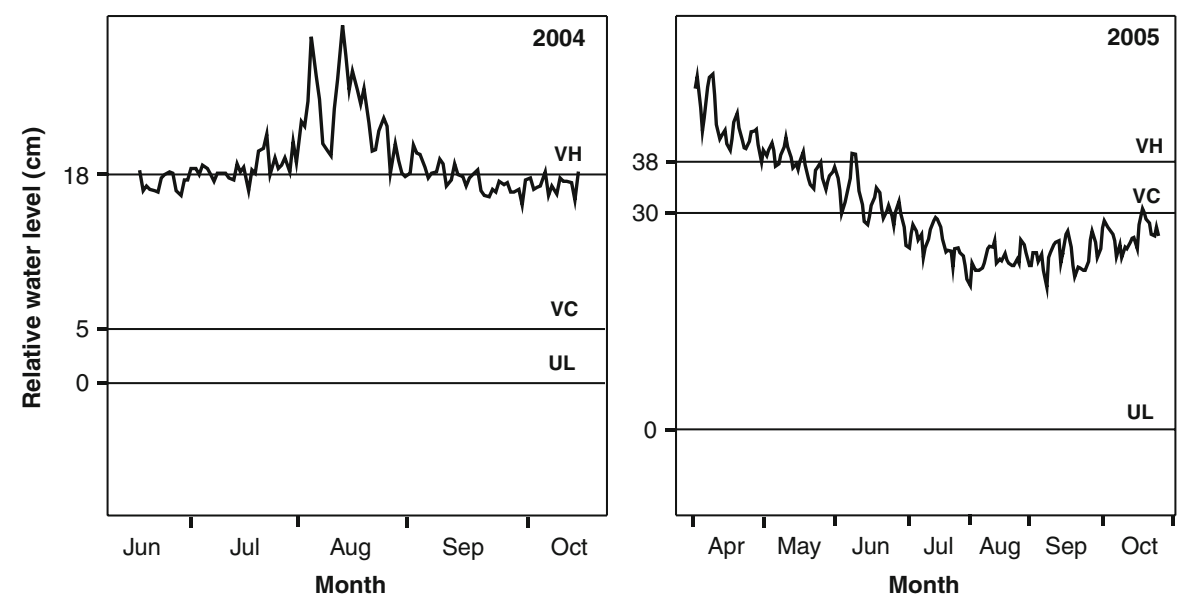


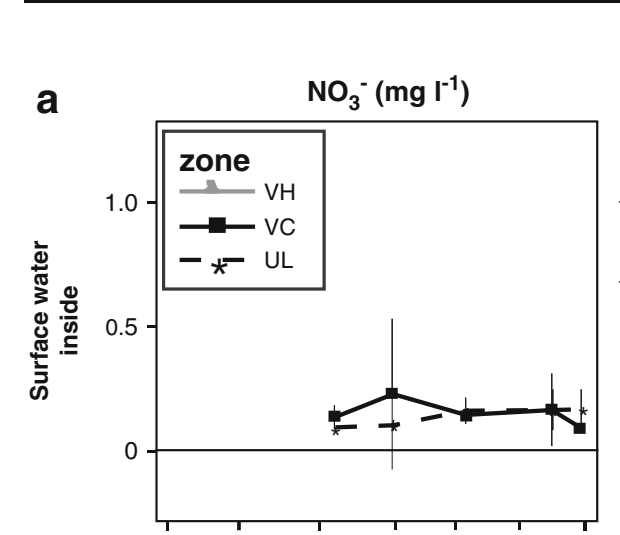

2004
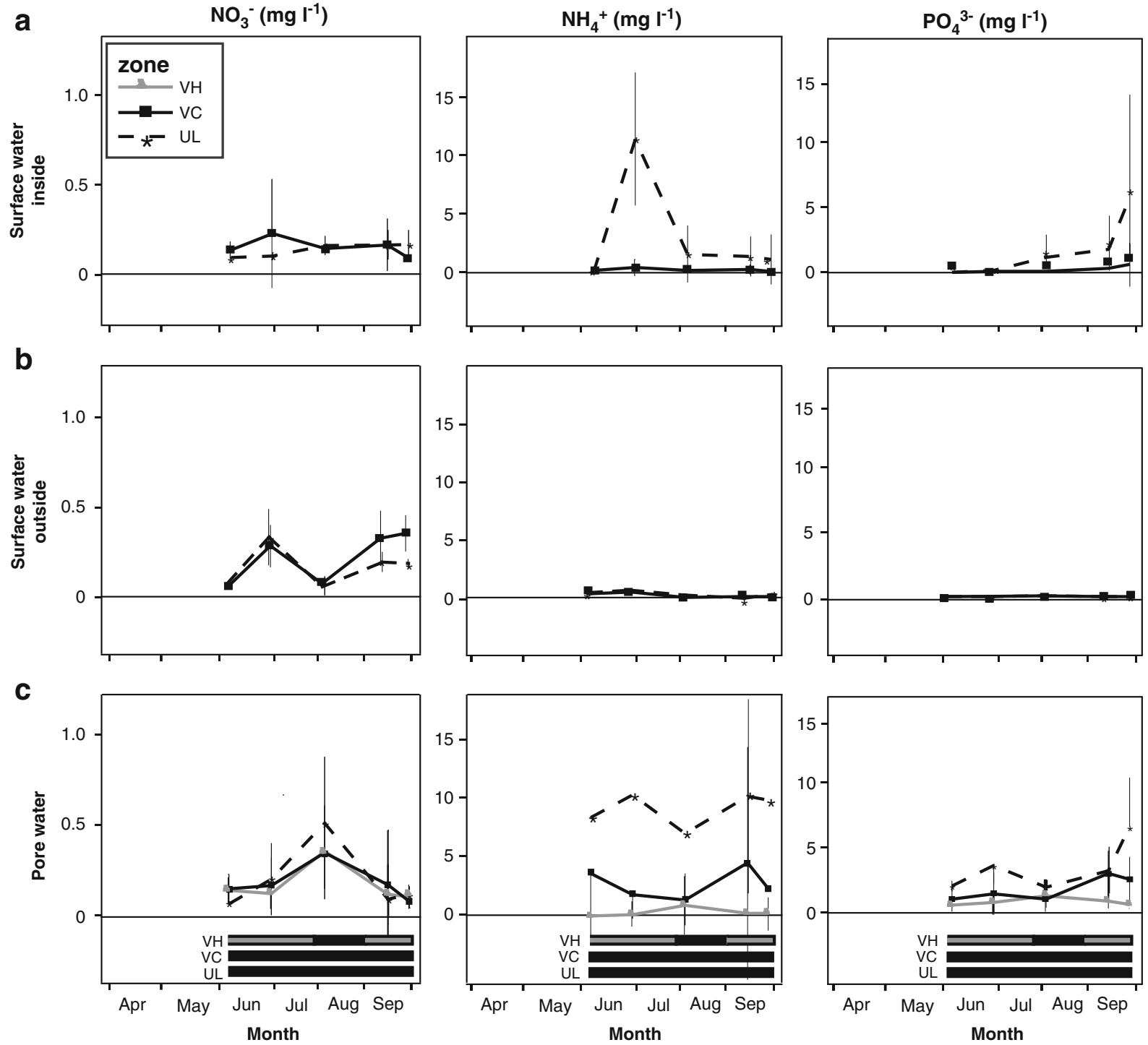

Fig. 3 a-c. Mean $\left( \pm\right.$ SE) nutrient concentrations $\left(\mathrm{mg} \mathrm{l}^{-1}\right)$ in the surface water (a) inside and (b) outside the cylinders and (c) in the pore water in the different littoral zones during the growing season of 2004. $V H$ vegetated, high on the lake shore, $V C$

vegetated, center, $U L$ unvegetated, low on the lake shore. $n=5$. Bars indicate flooded (black) or water at surface level (grey) periods

ences between zones). In the vegetated site, $\mathrm{pH}$ was significantly lower (around 7.5) than in the unvegetated zone (around 8.5) in 2004 as well as 2005 ( $p=$ 0.001 and $p<0.001$, respectively; data not shown).

\subsection{Pore Water}

Pore water nutrient concentrations were not influenced by the use of the cylinders and therefore only results from inside the cylinders are mentioned. EC in pore water was higher than in the surface water. In 2004 EC of the pore water was highest in the unvegetated zone (UL, around $10 \mathrm{mS} \mathrm{cm}{ }^{-1}$, decreasing to 6 in summer) and lowest (around $4 \mathrm{mS} \mathrm{cm}^{-1}$ ) in zone $\mathrm{VH}$. Zone VC was in between with values around $6 \mathrm{mS} \mathrm{cm}$. The zones all significantly differed from each other. In 2005 the values were lower (around $4 \mathrm{mS} \mathrm{cm}^{-1}$ for zones UL and $\mathrm{VC}$ ). Zone VH increased from August on from 4 to $25 \mathrm{mS}$ $\mathrm{cm}^{-1}$. Zone $\mathrm{VH}$ had a higher EC than zone VC $(p=$ 
2005
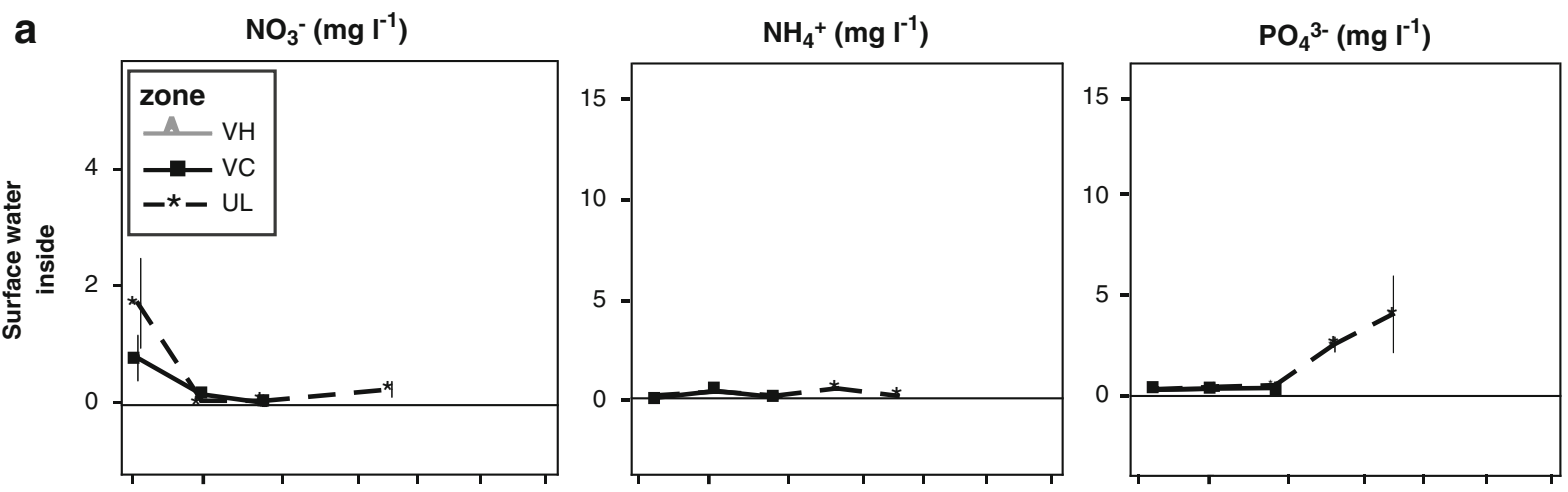

b
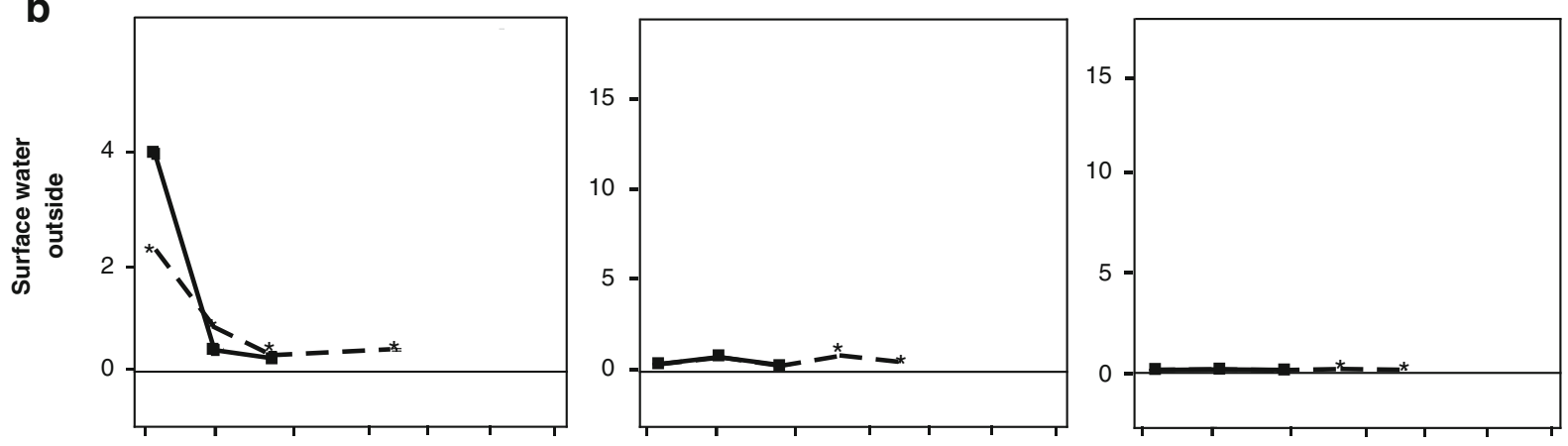

C
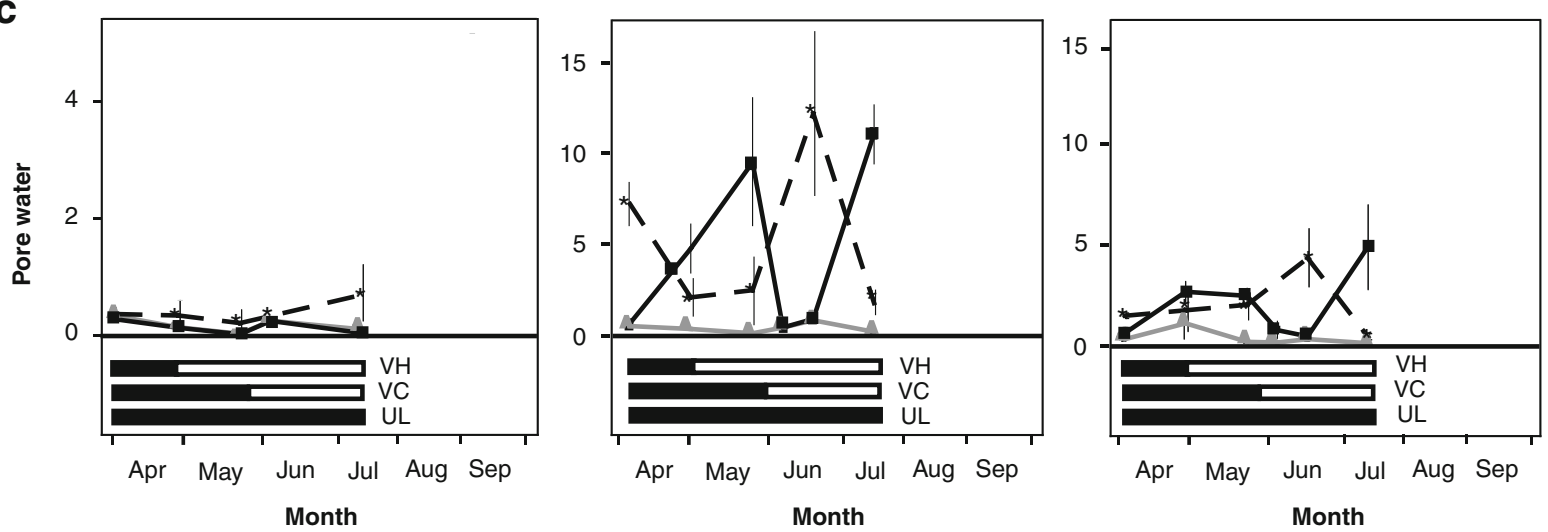

Fig. 4 a-c. Mean $\left( \pm\right.$ SE) nutrient concentrations $\left(\mathrm{mg} \mathrm{l}^{-1}\right)$ in the surface water (a) inside and (b) outside the cylinders and (c) in the pore water in the different littoral zones during the growing

$0.01)$ and zone UL $(p=0.006)$. Like for surface water, pore water $\mathrm{pH}$ was also higher in the unvegetated zone, compared to the vegetated zones $(p<0.001$ for comparisons of UL-VC and UL-VH in both years).

Nutrient concentrations in the pore water differed significantly between zones. The 2004 data (Fig. 3c) show that $\mathrm{NH}_{4}^{+}$and $\mathrm{PO}_{4}^{3-}$ concentrations were lower in the center zone with vegetation (VC) than in the unvegetated zone (both $p=0.013$ ). In 2005 no season of 2005. $V H$ vegetated, high on the lake shore, $V C$ vegetated, center, $U L$ unvegetated, low on the lake shore. $n=5$. Bars indicate flooded (black) and drained (white) periods

significant differences were found between the zones (Fig. 4c). In 2004 nitrate concentration peaked in July/August (significant time effect: $p<0.001$ ) and phosphate concentration increased during the season (significant time effect: $p=0.008$ ). Ammonium concentration remained stable throughout the growing season of 2004. In 2005 no seasonal effects were shown for the mean concentrations of $\mathrm{NO}_{3}^{-}, \mathrm{NH}_{4}^{+}$and $\mathrm{PO}_{4}^{3-}$ in the pore water. 


\subsection{Extractable and Total Nutrients}

$\mathrm{NO}_{3}^{-}, \mathrm{NH}_{4}^{+}$and $\mathrm{PO}_{4}^{3-}$ concentrations, measured by sediment extraction, all were higher in the unvegetated zone compared to the highest vegetated zone (VH; $p=0.034, p=0.018$ and $p=0.027$, respectively) in 2004 (Fig. 5). Between zones UL and zone VC no significant differences were measured. The average extractable nitrate and ammonium contents changed over time during the measured months. Nitrate had a significant peak in September (significant time effect; $p<0.001$ ) and phosphorus also increased at the end of the growing season (significant time effect; $p=0.024$ ).

The total $\mathrm{P}$ content of the sediment was higher in zone UL compared to zone VH $(p=0.072)$. TN concentration was higher in zone UL than in zone VH $(p=0.015)$. The other differences in TN and TP contents were not significant. Both $\mathrm{TN}$ and TP increased significantly from August on (significant time effect; $p<0.001$ ). These changes are not related to organic matter content (low values between 1 and $3 \%$, which was not significantly different between zones and within time.

\subsection{Comparison 2004 and 2005}

The comparison of the results of 2004 with 2005 (the constant water level with the decreasing water level) is shown in Table 1. Means of nutrient concentrations inside the cylinders over the whole measuring period were compared between the two years. Although the two years did not totally cover the same period, no significant season effect was expected on basis of Figs. 4 and 5. Nitrate concentration in the pore water was significantly higher in 2005 than in 2004 ( $p=$ 0.022 ), but only in the vegetated zone high on the lake shore. That zone was flooded part of 2004 and drained most of 2005. Ammonium and phosphate concentrations in the pore water of the high zone were comparable between the two water level regimes.
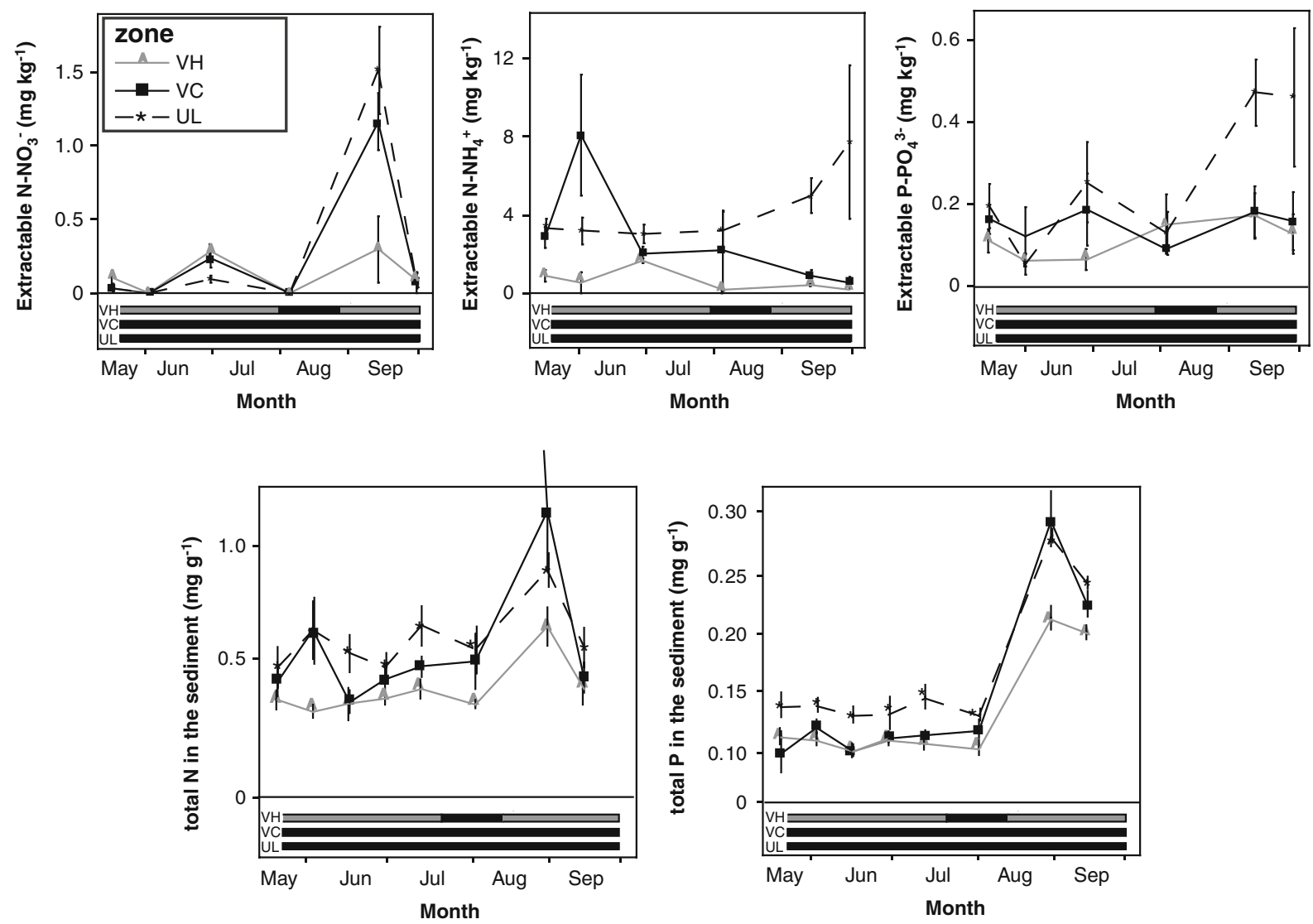

Fig. 5 Mean $( \pm \mathrm{SE})$ extractable $\left(\mathrm{mg} \mathrm{kg}^{-1}\right)$ and total $\left(\mathrm{mg} \mathrm{g}^{-1}\right)$ nutrient contents in the sediment in the different zones in 2004. $V H$ vegetated, high on the lake shore, $V C$ vegetated, center, $U L$

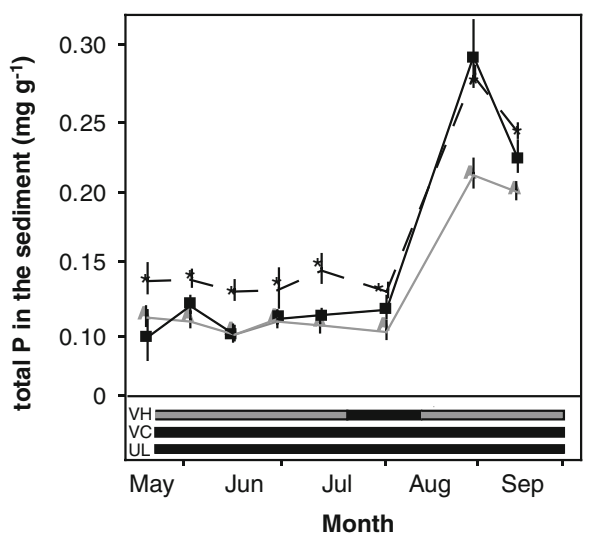

unvegetated, low on the lake shore. $n=5$. Bars indicate flooding (black) or water at surface level (grey) 
Table 1 Mean nutrient concentrations $\left(\mathrm{mg} \mathrm{l}^{-1}\right)$ during the growing season of surface water and pore water inside the cylinders and their statistical differences (significant differences $(p<$ 0.05 ) in bold) between 2004 and 2005. $n=5$

\begin{tabular}{|c|c|c|c|c|c|c|c|}
\hline \multirow[t]{2}{*}{ Variable } & \multirow[t]{2}{*}{ Year } & \multicolumn{2}{|l|}{$\mathrm{VH}$} & \multicolumn{2}{|l|}{$\mathrm{VC}$} & \multicolumn{2}{|l|}{ UL } \\
\hline & & Mean & $p$ & Mean & $p$ & Mean & $p$ \\
\hline \multirow[t]{2}{*}{$\mathrm{NO}_{3}^{-}$in surface water } & 2004 & & & 0.092 & 0.019 & 0.066 & 0.012 \\
\hline & 2005 & & & 0.430 & & 0.630 & \\
\hline \multirow[t]{2}{*}{$\mathrm{NH}_{4}^{+}$in surface water } & 2004 & & & 0.358 & 0.322 & 3.374 & 0.003 \\
\hline & 2005 & & & 0.270 & & 0.560 & \\
\hline \multirow[t]{2}{*}{$\mathrm{PO}_{4}^{3-}$ in surface water } & 2004 & & & 0.176 & 0.297 & 1.856 & 0.465 \\
\hline & 2005 & & & 0.054 & & 1.144 & \\
\hline \multirow[t]{2}{*}{$\mathrm{NO}_{3}^{-}$in pore water } & 2004 & 0.142 & 0.022 & 0.166 & 0.292 & 0.178 & 0.121 \\
\hline & 2005 & 0.238 & & 0.226 & & 0.446 & \\
\hline \multirow[t]{2}{*}{$\mathrm{NH}_{4}^{+}$in pore water } & 2004 & 0.798 & 0.774 & 3.014 & 0.488 & 9.174 & 0.042 \\
\hline & 2005 & 0.696 & & 4.272 & & 4.772 & \\
\hline \multirow[t]{2}{*}{$\mathrm{PO}_{4}^{3-}$ in pore water } & 2004 & 0.610 & 0.398 & 1.800 & 0.978 & 3.820 & 0.022 \\
\hline & 2005 & 0.288 & & 1.784 & & 1.796 & \\
\hline
\end{tabular}

The middle zone was continuously flooded in 2004 with about $13 \mathrm{~cm}$ of water, while in 2005 it was drained from June on. This did not result in significant differences in nutrient concentrations in the pore water. Means of surface water were only calculated from data before June, when surface water was present. In zone VC, nitrate concentration in the surface water was significantly higher in 2005 than in $2004(p=0.019)$. Ammonium and phosphate in both surface and pore water did not differ between the years.

In zone UL more significant differences were measured, although this zone was continuously flooded in both years. Nitrate and ammonium in surface water were higher in 2005 and 2004, respectively, while phosphate did not differ. Ammonium and phosphate in pore water were higher in 2004, while nitrate concentrations were comparable between the years.

\subsection{Correlation Between Nutrient Concentrations and Water Level}

In a regression analysis between nutrient concentrations and water level a linear relationship was the best fit (data not shown). Regression analysis was showed a significant positive correlation between water level (above sediment surface) and surface water nitrate in 2005, pore water nitrate (only 2005), ammonium (both years), and phosphate (only 2004) inside the cylinders (Table 2). In this regression dates when water level was below soil surface were omitted. Extractable ammonium and phosphate, as well as total
Table 2 Regression analysis between nutrient variables and water level in 2004 and 2005. Data of surface water inside the cylinders were used. Significant differences $(p<0.05)$ in bold. $(+)$ indicates a positive relation

\begin{tabular}{|c|c|c|c|c|}
\hline \multirow[t]{2}{*}{ Variable } & \multicolumn{2}{|l|}{2004} & \multicolumn{2}{|l|}{2005} \\
\hline & $\overline{R^{2}}$ & $p$ & $\overline{R^{2}}$ & $p$ \\
\hline $\mathrm{NO}_{3}^{-}$in surface water $\left(\mathrm{mg} \mathrm{l}^{-1}\right)$ & 0.015 & 0.411 & 0.057 & $0.027(+)$ \\
\hline $\mathrm{NH}_{4}^{+}$in surface water $\left(\mathrm{mg} \mathrm{l}^{-1}\right)$ & 0.040 & 0.177 & 0.001 & 0.812 \\
\hline $\mathrm{PO}_{4}^{3-}$ in surface water $\left(\mathrm{mg} \mathrm{l}^{-1}\right)$ & 0.042 & 0.168 & 0.008 & 0.563 \\
\hline $\mathrm{NO}_{3}^{-}$in pore water $\left(\mathrm{mg} \mathrm{l}^{-1}\right)$ & 0.019 & 0.257 & 0.072 & $0.027(+)$ \\
\hline $\mathrm{NH}_{4}^{+}$in pore water $\left(\mathrm{mg} \mathrm{l}^{-1}\right)$ & 0.424 & $0.000(+)$ & 0.051 & $0.041(+)$ \\
\hline $\mathrm{PO}_{4}^{3-}$ in pore water $\left(\mathrm{mg} \mathrm{l}^{-1}\right)$ & 0.261 & $0.000(+)$ & 0.028 & 0.128 \\
\hline Extractable $\mathrm{NO}_{3}^{-}\left(\mathrm{mg} \mathrm{kg}^{-1}\right)$ & 0.011 & 0.333 & 0.022 & 0.434 \\
\hline Extractable $\mathrm{NH}_{4}^{+}\left(\mathrm{mg} \mathrm{kg}^{-1}\right)$ & 0.201 & $0.000(+)$ & 0.370 & $0.000(+)$ \\
\hline Extractable $\mathrm{PO}_{4}^{3-}\left(\mathrm{mg} \mathrm{kg}^{-1}\right)$ & 0.099 & $0.003(+)$ & 0.004 & 0.728 \\
\hline Total $\mathrm{N}$ in sediment $\left(\mathrm{mg} \mathrm{g}^{-1}\right)$ & 0.119 & $0.000(+)$ & 0.013 & 0.555 \\
\hline Total $\mathrm{P}$ in sediment $\left(\mathrm{mg} \mathrm{g}^{-1}\right)$ & 0.039 & $0.031(+)$ & 0.073 & 0.148 \\
\hline
\end{tabular}


sediment $\mathrm{N}$ and $\mathrm{P}$ were also positively related to water level.

\subsection{Vegetation}

Reed biomass at the end of the growing season (September 30, 2004 and October 11, 2005) did not differ between zones $\mathrm{VH}$ and $\mathrm{VC}$ in 2004, while in 2005 biomass in VH was significantly lower than in the central zone VC ( $p=0.010$; Fig. 6). The higher biomass in $\mathrm{VC}$ compared to $\mathrm{VH}$ in 2005 was associated with greater stem length $(p<0.001)$ and diameter $(p=0.009)$ rather than a larger number of stems per square meter. The reed biomass at the end of the growing season in zone $\mathrm{VH}$ was significantly lower in 2005 than $2004(p=0.002)$. In 2005 maximum stand crop was measured in July. From July till October 2005 reed biomass did not increase ( $p=0.452$ for VH; $p=0.334$ for VC). Nutrient contents in the biomass $\left(\mathrm{g} \mathrm{m}^{-2}\right)$ at the end of the growing season were significantly higher in zone VC com- pared to zone $\mathrm{VH}$ in $2004(p<0.001$ for $\mathrm{N}, p=0.003$ for $\mathrm{P}$ ) as well as in 2005 ( $p=0.003$ for $\mathrm{N}$ and $p=0.002$ for $\mathrm{P})$. The differences in nutrient contents between 2004 and 2005 were significant for both zone VH $(p<$ 0.001 for both $\mathrm{N}$ and $\mathrm{P}$ ) and zone $\mathrm{VC}(\mathrm{N}: p=0.024$; P: $p=0.005$ ). These differences were not only caused by the differences in biomass but also by differences in nutrient concentrations $\left(\mathrm{mg} \mathrm{g}^{-1}\right)$. The $\mathrm{N}$ and $\mathrm{P}$ concentrations were higher in 2004 in zone VH $(\mathrm{N}$ : $p=0.002$; $\mathrm{P}: p<0.001)$ as well as in zone VC $(p<$ 0.001 for both $\mathrm{N}$ and $\mathrm{P}$ ).

\subsection{Denitrification}

Denitrification rate in 2005 varied between the zones as well as within the season (Fig. 7). In the unvegetated zone, in general, the rate was higher than in the other zones. There was a significant peak in May in zone UL and zone VC. In zone VH denitrification rate was low, especially when the zone was drained from May onwards. At that time denitrification rate was almost
Fig. 6 Mean $( \pm \mathrm{SE})$ aboveground biomass $\left(\mathrm{g} \mathrm{m}^{-2}\right)$ in 2004 (upper left) and 2005 (upper right), and $\mathrm{TN}$ (lower left) and TP (lower right) in standing stock $\left(\mathrm{g} \mathrm{m}^{-2}\right)$ of the two vegetated zones. Inside the bars nutrient concentrations ( $\mathrm{mg} \mathrm{g}^{-1}$ ) are shown. Significant differences $(p<0.05)$ of contents are shown between zones and within years (small letters within 2004 and capitals within 2005). $n=5$. $V H$ vegetated, high on the lake shore, $V C$ vegetated, center, $U L$ unvegetated, low on the lake shore
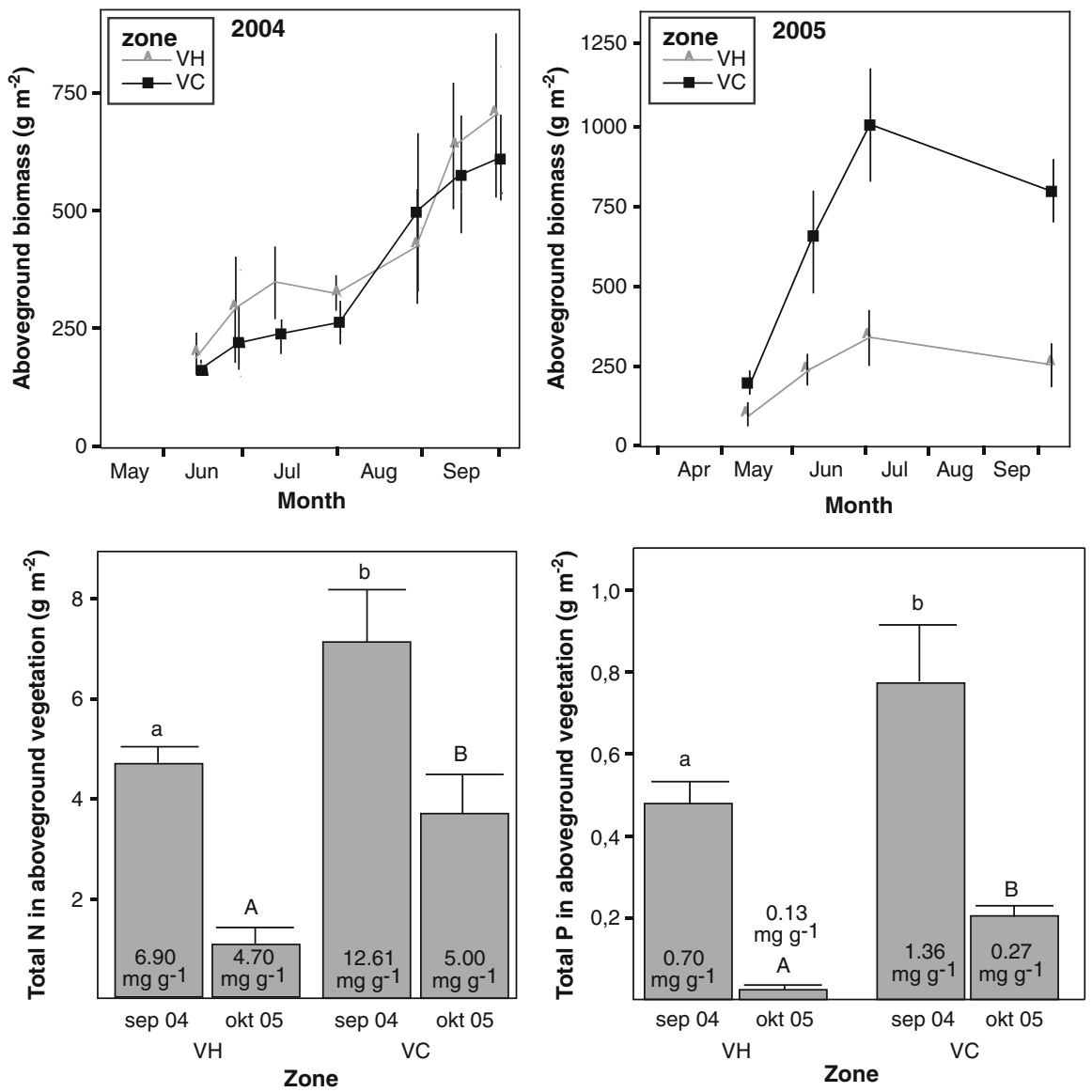


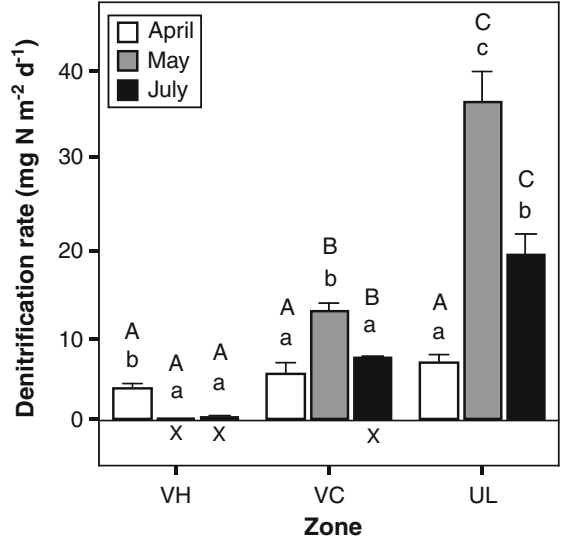

Fig. 7 Mean $\left( \pm\right.$ SE) denitrification rates $\left(\mathrm{mg} \mathrm{N} \mathrm{m}^{-2} \mathrm{~d}^{-1}\right)$ in the different littoral zones. $n=5$. $V H$ vegetated, high on the lake shore, $V C$ vegetated, center, $U L$ unvegetated, low on the lake shore. Significant differences $(p<0.05)$ are shown between zones (normal) and between months (capital). Drained sites are indicated with $X$

zero. Regression analysis between water level and denitrification rate showed a significant positive relation $\left(R^{2}=0.302 ; p<0.001\right)$. When the values are averaged within each zone, the average denitrification rate was 5,29 and $80 \mathrm{~kg} \mathrm{~N} \mathrm{ha}^{-1}$ year $^{-1}$ for the zones $\mathrm{VH}, \mathrm{VC}$ and UL, respectively.

\subsection{Nutrient Contents of System Compartments}

Nutrients in the different system compartments sediment, plant, surface water and pore water were calculated for September 2004 and June 2005. For the calculation the results of the sediment extraction, sediment digestion, plant digestion, pore water nutrient concentrations and surface water nutrient concentrations were used. These values were all converted into $\mathrm{mg} \mathrm{m}^{-2}$ using bulk density of the sediment $\left(\mathrm{kg} \mathrm{m}^{-3}\right)$, sediment depth $(0.1 \mathrm{~m})$, water height $(\mathrm{m})$, surface area cylinder $\left(0.45 \mathrm{~m}^{2}\right)$, moisture content $(\%)$, volume pore water $\left(\mathrm{m}^{-2}\right)$ and weight dry sediment of $10 \mathrm{~cm}$ depth $\left(\mathrm{kg} \mathrm{m}^{-2}\right)$. The values of the mobile nutrients can in this way be compared to the nutrient contents in the aboveground vegetation. In Table 3 correlation coefficients and $p$-values are shown for inorganic nutrients and vegetation. These correlations show that in general a negative correlation was found between $\mathrm{N}$ and $\mathrm{P}$ in the aboveground biomass and the

Table 3 Pearson's correlation coefficients and p-values between nutrients in the aboveground biomass and nutrients in surface water inside the cylinders (SW), pore water (PW) and sediment

\begin{tabular}{|c|c|c|c|c|c|}
\hline \multirow[t]{2}{*}{ Parameter } & \multirow[t]{2}{*}{ Pearson's correlation } & \multicolumn{2}{|c|}{$\mathrm{N}$ in aboveground biomass $\left(\mathrm{g} \mathrm{m}^{-2}\right)$} & \multicolumn{2}{|c|}{$\mathrm{P}$ in aboveground biomass $\left(\mathrm{g} \mathrm{m}^{-2}\right)$} \\
\hline & & Sept 2004 & June 2005 & Sept 2004 & June 2005 \\
\hline \multirow[t]{3}{*}{$\mathrm{N}$ in $\mathrm{SW}\left(\mathrm{mg} \mathrm{m}^{-2}\right)$} & Pearson's corr. & n.s. & -0.651 & & \\
\hline & $p$ & & 0.009 & & \\
\hline & $n$ & & 15 & & \\
\hline \multirow[t]{3}{*}{$\mathrm{N}$ in $\mathrm{PW}\left(\mathrm{mg} \mathrm{m}^{-2}\right)$} & Pearson's corr. & -0.662 & -0.661 & & \\
\hline & $p$ & 0.014 & 0.038 & & \\
\hline & $n$ & 13 & 10 & & \\
\hline \multirow[t]{3}{*}{ Extractable $\mathrm{N}$ in sediment $\left(\mathrm{mg} \mathrm{m}^{-2}\right)$} & Pearson's corr. & -0.837 & -0.587 & & \\
\hline & $p$ & 0.000 & 0.021 & & \\
\hline & $n$ & 14 & 15 & & \\
\hline \multirow[t]{3}{*}{$\mathrm{P}$ in $\mathrm{SW}\left(\mathrm{mg} \mathrm{m}^{-2}\right)$} & Pearson's corr. & & & -0.519 & -0.639 \\
\hline & $p$ & & & 0.057 & 0.010 \\
\hline & $n$ & & & 14 & 15 \\
\hline \multirow[t]{3}{*}{$\mathrm{P}$ in $\mathrm{PW}\left(\mathrm{mg} \mathrm{m}^{-2}\right)$} & Pearson's corr. & & & -0.644 & n.s. \\
\hline & $p$ & & & 0.018 & \\
\hline & $n$ & & & 13 & \\
\hline \multirow[t]{3}{*}{ Extractable $\mathrm{P}$ in sediment $\left(\mathrm{mg} \mathrm{m}^{-2}\right)$} & Pearson's corr. & & & -0.491 & n.s. \\
\hline & $p$ & & & 0.063 & \\
\hline & $n$ & & & 15 & \\
\hline
\end{tabular}

n.s. Not significant 
nutrient contents in surface water and sediment. These results are clearer for $\mathrm{N}$ than for $\mathrm{P}$.

\section{Discussion}

The goal of this research was to investigate the functioning of the lake littoral zone with respect to nutrient cycling and nutrient retention in sediment and vegetation at two different water level regimes. Cylinders were used to confine local surface water in one location during the whole season. Surface water entering the cylinders via the soil might be a negative side-effect since that water mainly has the chemical composition of pore water. However, in this experiment increases in water level were mainly caused by rainfall. In addition, in 2005 water level decreased during the season. It is therefore assumed that the effect of pore water on the surface water composition is negligible.

The most important results from this study are that nutrient concentrations in the sediment were affected by both vegetation biomass (Figs. 3, 4 and 5) and water level regime (Table 1) and that surface water had lower nutrient concentrations when emergent vegetation was present (Figs. 3 and 4). Furthermore, the natural water level regime involving a slow drop during the growing season did not result in a higher helophyte biomass compared to the regime with stable water levels (Fig. 6). Finally, in contrast to our expectations, denitrification rate was higher in the unvegetated zone than in the vegetated areas (Fig. 7). The effects of the presence of emergent vegetation and of water level fluctuations on nutrient retention are complex and will be discussed below.

The height gradient on the lake shore under study was reflected in nutrient cycling and nutrient retention. Two factors varied along the gradient: vegetation biomass and water level. Maximum aboveground reed biomass in the littoral zone of Lake Volkerak varied from 200 to $1,000 \mathrm{~g} \mathrm{~m}^{-2}$. These values are in the low range of the study of Gopal (1990) in which in 16 marsh studies above ground biomasses ranged between 180 and $5,280 \mathrm{~g} \mathrm{~m}^{-2}$. When comparing the high and the center zone, in 2004 biomass was comparable. However, in 2005 biomass in the high zone was three times lower than in the center zone. This might be due to the lower water level which fell below sediment surface in May in the high zone and in July in the center zone. Coops (1996) also found higher reed biomass in flooded conditions than in sites with water levels below sediment surface. The lower vegetation biomass in the high zone might also be related to a high salinity after drawdown. This would also explain the inhibited growth of the aboveground reed biomass from July 2005 on. Lake Volkerak is a former estuarine system and consequently sodium chloride concentrations in the sediment are still high. Due to the drawdown in May and the continuing evapotranspiration by the vegetation, EC in the highest zone increased to $25 \mathrm{mS} \mathrm{m}^{-2}$ (equivalent to salinity of $10 \mathrm{~g} \mathrm{l}^{-1}$ ). Howard and Rafferty (2006) and Mauchamp and Mésleard (2001) showed a negative effect of salinity on the growth of Phragmites australis.

The effects of helophyte vegetation on pore water nutrients and extractable nutrients were obvious. The overall trend showed occasional, high ammonium and phosphate peaks in the unvegetated zone that were absent in the vegetated zones. Nitrogen and phosphorus contents in surface water and pore water were negatively correlated to nutrient contents in the aboveground vegetation. Several mechanisms could be involved. Nutrient concentrations may have been reduced by direct uptake by helophytes (Huet et al. 2005). Another possibility is the oxidation of the sediment by root gas exchange (Matsui and Tsuchiya 2006; Gries et al. 1990). A higher frequency of oxic microsites would increase nitrification rates (Tanner et al. 1999; Patrick and Reddy 1976) and result in adsorption of phosphate to oxidized iron. Nitrate could then be transported to anoxic microsites and denitrified there. In the study of Patrick and Reddy (1976) the source of half of the denitrified $\mathrm{N}$ was ammonium originally present in the surface aerobic layer. In this study denitrification rate varied between 0 and $139 \mathrm{~kg} \mathrm{ha}^{-1}$ year $^{-1}$. These values are in the mid range compared to other studies. Olde Venterink et al. (2003) found a rate of $55 \mathrm{mg} \mathrm{N} \mathrm{m}{ }^{-2}$ day $^{-1}$ in a flooded reed bed of a Dutch floodplain. Hasegawa and Okino (2004) measured an average of $93 \mathrm{~kg} \mathrm{ha}^{-1}$ year $^{-1}$ at $4 \mathrm{~m}$ depth in a lake in Japan. Hefting et al. (2003) measured values up to $183 \mathrm{~kg} \mathrm{~N} \mathrm{ha}^{-1}$ year $^{-1}$ in a grassland riparian buffer zone with a water table just below sediment surface. The results of the denitrification measurements do not support the assumption that vegetation stimulates denitrification by aerating the soil via root gas exchange (Matsui and Tsuchiya 
2006; Gries et al. 1990). In our experiments vegetation presence had a negative influence on the denitrification rate. An explanation could be competition for nitrate by plant roots (Korsaeth et al. 2001). The fact that in the unvegetated zone nitrate concentration in the surface water was higher than in the vegetated zone also supports that explanation. However, nitrate was still present in the pore water in the vegetated zones and thus had not been depleted. This suggests that nitrification is not limiting denitrification. Total denitrification rate is probably underestimated in the vegetated zone. Toet et al. (2003) and Sirivedhin and Gray (2006) showed the importance of measuring denitrification rates in periphyton with higher values than measured in sediment.

Water level regime is another steering factor in nutrient cycling. In this study it is difficult to distinguish the separate effects of vegetation and water level. A positive correlation between denitrification rate and water level was found. The highest water depth was present in the unvegetated zone and it was flooded year-round. Although no studies were found concerning the relation between surface water level and denitrification rate, a clear drop in denitrification rates when water level dropped below ground level was seen. Air entering the soil inhibits denitrification (Patrick and Reddy 1976). Factors found to be correlated with denitrification rate in other studies, such as nitrate concentration (Davidsson and Leonardson 1998; Hasegawa and Okino 2004), temperature (Pribyl et al. 2005) and organic matter content (Saunders and Kalff 2001) did not show significant correlations in our study. A direct effect of salinity on denitrification rates is not likely (Magalhães et al. 2005; Fear et al. 2007). Like denitrification rate also pore water nutrients were dependent on water level, although again the effects of vegetation and water level are interacting. At higher water levels higher pore water phosphate and ammonium concentrations were found, as also found by Newman and Pietro (2001).

It was expected to find effects of water level and vegetation also on surface water quality, because there is an exchange of nutrients between surface water and sediment pore water through diffusion and vertical water movement. Downward water flow is expected to be enhanced by evapotranspiration in summer (Koerselman and Beltman 1988). Our results show that surface water ammonium and phosphate concen- trations were lower in the vegetated zone, as also found by Coveney et al. (2002), Kufel and Kufel (2002) and Krolikowska (1997). Furthermore, the negative correlation between nutrients in the vegetation and in the surface water indicates a direct effect of the vegetation. The results of nutrient concentrations outside the cylinders show the mixing of surface water and thereby obscuring the differences between the zones.

From our results it is obvious that the functioning of littoral zones is different along a gradient from high to low soil elevation and from vegetated to unvegetated in the growing season. Plant uptake and denitrification is dependent on the location along a lake shore. During spring and summer the removal of nitrogen from the system by denitrification was highest in the flooded zones, especially in the zone without vegetation. Nutrient contents in the peak standing crop of Phragmites australis were also dependent on location along the lake shore. High on the littoral gradient, in seasonally dry zones, significantly less nutrients were stored in P. australis than when the sediment remained flooded. Furthermore, a significant decrease in nutrient concentrations in sediment and surface water was seen in the vegetated zone compared to the unvegetated zone. It has to be kept in mind that presented results are only covering the spring and summer season. Most of the nutrients are retained for a long time in the vegetation, although a significant part of the nutrients may return to the lake water and sediments at the end of the vegetation season (Krolikowska 1997). Winter results should be included to draw conclusion on annual mean retention capacity. In contrast to vegetation storage, denitrification is a permanent removal process (Patrick and Reddy 1976), which is also strongly dependent on season (Davidsson and Leonardson 1998; Hasegawa and Okino 2004).

On basis of our experiment, it can be concluded that for an optimal nutrient retention during the growing season, a natural water level management with a drop during spring and summer is not necessarily better suited than a stable water level. However, on the longer term and on a larger scale, the width of the vegetated zone has been shown to increase substantially if a regime of stable water levels is modified to a regime with seasonally falling water levels in the summer (Coops et al. 2004). On the other hand, at fluctuating water levels problems 
might arise when rewetting after a period of drainage. Phosphate might be released (Watts 2000; Baldwin et al. 2000) to undesirable levels. It is important to optimize conditions for helophyte growth since the positive effect of vegetation on water quality, at least at local scale, has been demonstrated in this study and, in lakes where water level regime can be influenced, a fluctuating water level regime might still be optimal for water quality.

Acknowledgements This research was conducted in the project 'Water level management and nutrients in shallow lakes' financed by the RIZA (Institute for Inland Water Management and Waste Water Treatment). The authors wish to thank Rijkswaterstaat Zeeland for field access. Special thanks to Jaap Daling for managing the pumping system and Evelyn Parh for her useful help in field and laboratory. Furthermore, thanks to all colleagues of Landscape Ecology who joined in the field trips.

Open Access This article is distributed under the terms of the Creative Commons Attribution Noncommercial License which permits any noncommercial use, distribution, and reproduction in any medium, provided the original author(s) and source are credited.

\section{References}

Baldwin, D. S., Mitchell, A. M., \& Rees, G. N. (2000). The effects of in situ drying on sediment-phosphate interactions in sediments from an old wetland. Hydrobiologia, $431,3-12$.

Bratli, J. L., Skiple, A., \& Mjelde, M. (1999). Restoration of lake Borrevannet-Self-purification of nutrients and suspended matter through natural reed-belts. Water Science and Technology, 40, 325-332.

Bray, R. H., \& Kurtz, L. T. (1945). Determination of total, organic, and available forms of phosphorus in soils. Soil Science, 59, 39-45.

Bremner, J. M., \& Mulvaney, C. S. (1982). Salicylic acidthiosulphate modification of Kjeldahl method to include nitrate and nitrite. In A. C. Page, R. H. Miller, \& D. R. Keeney (Eds.) Methods of soil analysis, Part 2 (pp. 621622). Madison: American society of Agronomy.

Coops, H. (1996). Helophyte zonation - impact of water depth and wave exposure. Dissertation: Catholic University Nijmegen.

Coops, H., Van den Brink, F. W. B., \& Van der Velde, G. (1996). Growth and morphological responses of four helophyte species in an experimental water-depth gradient. Aquatic Botany, 54, 11-24.

Coops, H., Vulink, J.Th, \& Van Nes, E. H. (2004). Managed water levels and the expansion of emergent vegetation along a lakeshore. Limnologica, 34, 57-64.

Coveney, M. F., Stites, D. L., Lowe, E. F., Battoe, L. E., \& Conrow, R. (2002). Nutrient removal from eutrophic lake water by wetland filtration. Ecological Engeneering, 19, $141-159$.
Davidsson, T. E., \& Leonardson, L. (1998). Seasonal dynamics of denitrification activity in two water meadows. Hydrobiologia, 364, 189-198.

Dobson, M., \& Frid, C. (1998). Lakes and ponds. In M. Dobson, \& C. Frid (Eds.) Ecology of aquatic systems (pp. 134-157). Harlow: Addison Wesley Longman Limited.

Fear, J. M., Thompson, S. P., Gallo, T. E., \& Paerl, H. W. (2007). Denitrification rates measured along a salinity gradient in the eutrophic Neuse River estuary, North Carolina, USA. Estuaries and Coasts, 28(4), 608-619.

Gopal, B. (1990). Biology and ecology. In B.C. Patten (Ed.) Wetlands and shallow continental water bodies, Vol. 1 (pp. 91-239). The Hague: SPB Academic Publishing.

Gries, C., Kappen, L., \& Losch, R. (1990). Mechanism of flood tolerance in reed, Phragmites australis (Cav) Trin Ex Steudel. New Phytologist, 114, 589-593.

Hasegawa, T., \& Okino, T. (2004). Seasonal variation of denitrification rate in Lake Suwa sediment. Limnology, 5, 33-39.

Hefting, M. M., Bobbink, R., \& De Caluwe, H. (2003). Nitrous oxide emission and denitrification in chronically nitrateloaded riparian buffer zones. Journal of Environmental Quality, 32, 1194-1203.

Houba, V. J. G., Van der Lee, G. E. M., Novozamsky, I., \& Walinga, I. (1989). Soil and plant analysis: A series of syllabi. Part 5. Soil analysis procedures. The Netherlands: Wageningen Agricultural University.

Howard, R. J., \& Rafferty, P. S. (2006). Clonal variation in response to salinity and flooding stress in four marsh macrophytes of the northern gulf of Mexico, USA. Environmental and Experimental Botany, 56, 301-313.

Huet, D. O., Morris, S. G., Smith, G., \& Hunt, N. (2005). Nitrogen and phosphorus removal from plant nursery runoff in vegetated and unvegetated subsurface flow wetlands. Water Research, 39, 3259-3272.

Koerselman, W., \& Beltman, B. (1988). Evapotranspiration from fens in relation to Penman's potential free water evaporation $\left(\mathrm{E}_{0}\right)$ and pan evaporation. Aquatic Botany, 31, 307-320.

Köhler, J., Hilt, S., Adrian, R., Nicklisch, A., Kozerski, H. P., \& Walz, N. (2005). Long-term response of a shallow, moderately flushed lake to reduced external phosphorus and nitrogen loading. Freshwater Biology, 50, 16391650 .

Korsaeth, A., Molstad, L., \& Bakken, L. R. (2001). Modelling the competition for nitrogen between plants and microflora as a function of soil heterogeneity. Soil Biology \& Biochemistry, 33, 215-226.

Krolikowska, J. (1997). Eutrophication processes in a shallow, macrophyte-dominated lake - species differentiation, biomass and the distribution of submerged macrophytes in Lake Luknajno (Poland). Hydrobiologia, 342/343, 411-416.

Kufel, L., \& Kufel, I. (2002). Chara beds acting as nutrient sinks in shallow lakes - A review. Aquatic Botany, 72, 249-260.

Magalhães, C. M., Joye, S. B., Moreira, R. M., Wiebe, W. J., \& Bordalo, A. A. (2005). Effect of salinity and inorganic nitrogen concentrations on nitrification and denitrification rates in intertidal sediments and rocky biofilms of the Douro River estuary, Portugal. Water Research, 39(9), 17831794. 
Matsui, T., \& Tsuchiya, T. (2006). A method to estimate practical radial oxygen loss of wetland plant roots. Plant and Soil, 279, 119-128.

Mauchamp, A., \& Mésleard, F. (2001). Salt tolerance in Phragmites australis populations from coastal Mediterranean marshes. Aquatic Botany, 70, 39-52.

Meuleman, A. F. M., Beekman, J. P., \& Verhoeven, J. T. A. (2002). Nutrient retention and nutrient-use efficiency in Phragmites australis stands after waste water application. Wetlands, 22, 712-721.

Newman, S., \& Pietro, K. (2001). Phosphorus storage and release in response to flooding: Implications for Everglades stormwater treatment areas. Ecological Engineering, 18, 23-38.

Olde Venterink, H., Hummelink, E., \& Van den Hoorn, M. W. (2003). Denitrification potential of a river floodplain during flooding with nitrate-rich water: Grasslands versus reedbeds. Biogeochemistry, 65, 233-244.

Patrick, W. H., \& Reddy, K. R. (1976). Nitrification-denitrification reactions in flooded soils and water bottoms: dependence on oxygen supply and ammonium diffusion. Journal of Environmental Quality, 5, 469-472.

Pribyl, A. L., McCutchan, J. H., Lewis, W. M., \& Saunders, J. F. (2005). Whole-system estimation of denitrification in a plains river: A comparison of two methods. Biogeochemistry, 73, 439-455.

Ryden, J. C., Skinner, J. H., \& Nixon, D. J. (1987). Soil core incubation system for the field measurement of denitrifi- cation using acetylene inhibition. Soil Biology and Biochemistry, 19, 753-757.

Saunders, D. L., \& Kalff, J. (2001). Denitrification rates in the sediments of Lake Memphremagog, Canada-USA. Water Research, 35, 1897-1904.

Scheffer, M. (1998). Ecology of shallow lakes. London: Chapman and Hall.

Sirivedhin, T., \& Gray, K. A. (2006). Factors affecting denitrification rates in experimental wetlands: Field and laboratory studies. Ecological Engineering, 26, 167-181.

Tanner, C. C., D’Eugenio, J., McBride, G. B., Sukias, J. P. S., \& Thompson, K. (1999). Effect of water level fluctuation on nitrogen removal from constructed wetland mesocosms. Ecological Engineering, 12, 67-92.

Toet, S., Huibers, L. H. F. A., Van Logtestijn, R. S. P., \& Verhoeven, J. T. A. (2003). Denitrification in the periphyton associated with plant shoots and in the sediment of a wetland system supplied with sewage treatment plant effluent. Hydrobiologia, 501, 29-44.

Tosserams, M., Vulink, J.Th. \& Coops, H. (1999). Tussen Water en Land-Perspectief voor Oeverplanten in het Volkerak-Zoommeer. RIZA rapport 99.031. In Dutch.

Verhoeven, J. T. A., \& Meuleman, A. F. M. (1999). Wetlands for wastewater treatment: Opportunities and limitations. Ecological Engineering, 12, 5-12.

Watts, C. J. (2000). Seasonal phosphorus release from exposed, re-inundated littoral sediments of two Australian reservoirs. Hydrobiologia, 431, 27-39. 